\title{
KRITIK TERHADAP KOMPILASI HUKUM ISLAM TENTANG KETENTUAN HARTA BERSAMA DALAM PERKAWINAN
}

\author{
Elimartati ${ }^{1}$, Elfia $^{2}$ \\ ${ }^{1}$ Istitut Agama Islam Negeri (IAIN) BatusangkarFakultas Syariah \\ e-mail: elimartati@iainbatusangkar.ac.id \\ 2Universitas Islam Negeri (UIN) Imam Bonjol Padang \\ e-mail: elfiamag@uinib.ac.id
}

\begin{tabular}{|l|l|l|}
\hline Submit: 18-07-2020 & $\begin{array}{l}\text { Direvisi: 27-08-2020, } \\
\text { 10-09-2002 }\end{array}$ & Dipublish: 18-12-2020 \\
\hline
\end{tabular}

\begin{abstract}
The development and social change of the community gives impact to the regulation of the collective assets of marriage. This paper will analyse the State Act of No.1 year 1974 the $35^{\text {th }}$ Article and the compilation of Islamic law (KHI) especially the Article of $1 f$ stating about the definition of the collective asset. This research is a normative law research. It used qualitative approach. Data was analysed through content analysis. Some of the finding shows that personal property and asset becomes the collective asset caused by the marital status. Actually this changing should be stated and witnessed by the penghulu who committed the couple at the beginning of the marriage. The purpose is to avoid illegal changing of the property or asset. The regulation in Indonesia has not yet organized this case as well as possible. It must be reformulated again. Colletive asset causes the changing of responsibility to a busband in giving money to live his wife. In KHI especially in Article 80 described about the the property and asset which can be used to making a living; they are personal asset and or shared asset gathering along the marriage.
\end{abstract}

Kata kunci: Hukum Islam, Harta bersama, Perkawinan.

\section{PENDAHULUAN}

$\mathcal{H}$ arta bersama dalam perkawinan mulanya bersumber dari adat istiadat ('urf) masyarakat suatu negeri yang tidak memisahkan hak milik suami-istri. Pencarian suami bercampur baur dengan hasil pencarian istri. Dalam rumah tangga seperti ini, rasa kebersamaan lebih menonjol. (Zein, 2004: 60) Harta seperti ini dalam masyarakat di Indonesia lebih dikenal dengan Gana-Gini. Di Aceh dinamakan dengan heureta sihaurekat, di Minangkabau dikenal dengan nama harta suarang, di Sunda diberi nama guna kaya, atau tumpang kaya, (di Kabupaten Sumedang) atau sarikat (di Kabupaten
Kuningan), di Jakarta dinamakan harta pencaharian, di Jawa dinamakan barang gana atau gono gini, di Bali disebut drube gabro, di Kalimantan disebut barang perpantangan, di Sulawesi (Bugis dan Makasar) dikenal dengan barang cakara, dan di Madura dikenal dengan nama ghuna-ghana. (Dahlan, 1997: 389; Rochaity, 2013)

Masyarakat adat Minangkabau menyebutkan harta bersama dalam perkawinan diperoleh selama berlangsung perkawinan, baik atas usaha suami, atau istri, atau usaha bersama suami istri. (Syarifuddin, 1984: 222) Bentuk harta inilah yang terjadi dalam kehidupan 
masyarakat Minangkabau sampai sekarang. Terbentuknya hubungan yang baik antara suami istri sangat membantu terbentuknya harta bersama dalam perkawinan. Suami sebagai kepala rumah tangga berkewajiban mencari nafkah untuk memenuhi kebutuhan rumah tangga dan istri sebagai ibu rumah tangga berkewajiban mengurus segala keperluan rumah tangga. Dengan begitu, maka terciptalah kerjasama yang baik antara suami istri. (Bushar, 1998: 17) isteri menjalankan kewajibannya mengurus rumah tangga, mengabdikan dirinya untuk sang suami selama siang malam, merawat mendidik dan menjaga anak maka pekerjaan isteri tersebut juga dihitung sebagai kontribusi yang sama dengan pekerjaan suami di luar rumah. (Kurniawan 2017: 28)

Adat kebiasaan terhadap harta bersama di Indonesia, ditetapkan dalam dalam Undang-Undang Nomor 1 Tahun 1974 tentang Perkawinan. pasal 35 dan Kompilasi Hukum Islam pasal 1 f. Yang disebut harta bersama dalam perkawinan. (harta yang diperoleh selama ikatan perkawinan berlangsung. Perolehannya tanpa mempersoalkan terdaftar atas nama siapapun). Menganalisis kitab fikih tidak dikenal adanya percampuran harta suami istri setelah berlangsungnya perkawinan. Suami memiliki hartanya sendiri dan istri memiliki hartanya sendiri. Sebagai kewajibanya, suami memberikan sebahagian hartanya kepada istrinya atas nama nafkah, yang digunakan oleh istri untuk memenuhi kebutuhan rumah tangganya. Tidak ada penggabungan harta, kecuali dalam bentuk syirkah (persyerikatan). Tanpa adanya akad tertentu, harta masing-masing suami istri tetap terpisah. (Elimartati, 2018: 2)
Pelakasanaan konsep harta bersama dalam perkawinan, bila dipahami apa yang dijelaskan Kompilasi Hukum Islam Pasal $1 \mathrm{f}$, seolah- seolah harta bersama itu terjadi dengan otomatis. Kriteria dari harta bersama dalam perkawinan itu juga tidak jelas, serta bagaimana tanggungjawab dan pengawasan suami-istri terhadap harta bersama. Pengertian harta bersama yang dijelaskan dalam undangundang dan KHI, membawa pemahaman yang rancu terhadap ketentuan kewajiban suami menafkahi keluarganya, bagaimana pelaksanaan nafkah bagi kelurga yang mengikuti prinsip harta bersama dan apa bedanya dengan keluarga yang tidak mengikuti prinsip harta bersama. Bila istri memperoleh penghasilan dari usahanya sendiri, bagaimana kedudukan hartanya, apakah ada kewajiban istri untuk membiayai rumah tangganya. Bagaimana pula implikasi harta pencarian isteri terhadap harta bersama. Menganalisis putusan hakim tentang pembahagian harta bersama dalam perkawinan, terdapat berbagai pertimbangan hakim dan putusan sesuai dengan kondisi dan andil usaha masing-masing suami dan istri, terdapat variasi putusannya dengan berbagai pertimbangan. Tulisan ini membahas masalah masalah yang disebutkan di atas.

\section{METODE PENELITIAN}

Penelitian ini merupakan penelitian yang berkaitan dengan yuridis formal. Jenis yang digunakan adalah penelitian hukum normatif memakai pendekatan kualitatif. Data yang dikumpulkan berupa data sekunder dengan bahan hukum primernya Undang-Undang Nomor 1 Tahun 1974 tentang Perkawinan dan Kompilasi Hukum Islam serta Putusan 
Pengadilan. Bahan hukum sekunder terdiri dari hasil penelitian, jurnal. Bahan hukum terstier berupa kamus, Ensiklopedi. Data yang diperoleh dari sumber penelitian dianalisis secara conten analisis. Melakukan telaah naskah untuk mengambil data tentang masalah yang diteliti dan dilakukan interpretasi dan analisis yang akhirnya membangun pemahaman-pemahaman baru tentang kritik terhadap kompilasi hukum Islam tentang ketentuan harta bersama dalam perkawinan.

\section{PEMBAHASAN}

Pembahasan harta bersama secara komprehensif oleh para fukaha diakui juga sebagai fikih kontemporer (fikih baru). Bustanul Arifin menyebutkan hal tersebut disebabkan karena pemahaman syariat waktu kitab-kitab fikih tersebut ditulis ketika keadaan masyarakat belum mengenal konsep harta bersama. (Arifin 1996: 122) Harta bersama di Indonesia dikenal melalui hukum adat yang diterapkan secara terus menerus sebagai hukum yang hidup dalam masyarakat. Lembaga harta bersama ditetapkan berdasarkan mashlahat walaupun masih ada dampak mudharatnya. Atas dasar metodologi maṣlahah mursalah, 'urf, dan kaidah al-'ādah al-muhakkamah (adat dapat menjadi hukum). Ulama melakukan pendekatan kompromistis kepada hukum adat. Selain pendekatan kompromistis, Ismuha dalam disertasinya mengembangkan pendapat bahwa pencaharian bersama suami istri mestinya masuk dalam rub' muamalat tetapi secara khusus tidak dibicarakan. Mungkin hal ini disebabkan karena pada umumnya pengarang dari kitab-kitab tersebut adalah orang Arab, sedangkan adat Arab tidak mengenal adat harta bersama. Di sana dibicarakan mengenai matä' al-bayt dan masalah perkongsian yang dalam bahasa Arab disebut syirkah. (Ismuha, 1978: 282)

Harta yang diperoleh suami dan istri dari usahanya menjadi harta bersama, baik mereka bekerja bersama-sama atau hanya suami saja yang bekerja. Apabila mereka telah mengikatkan diri dalam perkawinan sebagai suami-istri, maka semuanya menjadi bersatu, baik dalam bentuk harta maupun terhadap anak-anak mereka. Bila perkawinan telah terjadi, dengan adanya ijab dan qabul serta terpenuhinya persyaratan dalam perkawinan seperti adanya wali, saksi, mahar dan walimah, maka harta yang diperoleh dalam perkawinan menjadi harta bersama (UU Perkawinan dan KHI). Meski dalam memperoleh harta bersama tersebut hanya suami yang bekerja dengan berbagai usahanya sedangkan istri berada di rumah dengan tidak mencari nafkah melainkan hanya mengurus rumah tangga dan anak-anaknya. Nilai-nilai hukum baru dalam harta bersama yang dijelaskan dalam Undang-Undang Perkawinan Pasal 35 ayat 1, yang diperkuat dalam Kompilasi Hukum Islam dikemukakan bahwa harta bersama suami istri itu adalah harta yang diperoleh selama ikatan perkawinan berlangsung. Terbentuknya hubungan yang baik antara suami istri sangat membantu terbentuknya harta bersama dalam perkawinan. Suami sebagai kepala rumah tangga berkewajiban mencari nafkah untuk memenuhi kebutuhan rumah tangga dan istri sebagai ibu rumah tangga 
berkewajiban mengurus segala keperluan rumah tangga. Dengan begitu, maka terciptalah kerjasama yang baik antara suami istri. (Bushar, 1998: 17-20) Harta suami-istri dilihat dari sudut asal usulnya dapat dikategorikan kepada tiga bentuk; Pertama harta bawaan, yaitu harta yang telah dimiliki oleh suami-istri sebelum mereka menikah yang berasal dari harta warisan, hibah atau usaha mereka sendirisendiri. Kedua, harta suami atau istri dimiliki setelah perkawinan, yang diperoleh bukan dari usaha mereka secara pribadi atau bersama-sama, tetapi merupakan hibah, wasiat atau warisan masing-masing; Ketiga harta bersama yang diperoleh setelah pernikahan yang berasal dari hasil usaha mereka masingmasing suami atau istri, atau usaha mereka berdua yang disebut harta bersama. (Thalib, 1986: 83)

\section{HARTA BERSAMA PERKAWINAN DALAM HUKUM ISLAM}

Kitab fikih tidak mengenal adanya percampuran harta suami istri setelah berlangsungnya perkawinan. Suami memiliki hartanya sendiri, baik harta yang dimilikinya sebelum perkawinan atau harta yang diperolehnya dalam perkawinan, baik bersumber dari warisan, hibah atau hasil usahanya sediri. Begitu juga istri memilki hartanya sendiri, baik yang dimilikinya sebelum perkawinan atau harta yang diperolehnya dalam perkawinan, baik yang bersumber dari warisan, hibah dan hasil usahanya sendiri. Hal ini sesuai dengan apa yang dinyatakan Allah SWT dalam firman-Nya surat al-Nisa' ayat 32 "Dan janganlah kamu iri hati terhadap apa yang dikaruniakan Allah kepada sebahagian kamu lebih banyak dari sebahagian yang lain. (karena) bagi orang laki- laki ada bahagian dari pada apa yang mereka usahakan, dan bagi para perempuan (pun) ada bahagian dari apa yang mereka usahakan, dan mohonlah kepada Allah sebagian dari karuniaNya. Sesungguhnya Allah Maha mengetahui segala sesuatu." (QS. Al-Nisa' [3]: 32)

Ar-Raghib al-Asfahani berpendapat bahwa bahwa kata iktasaba (apa yang mereka usahakan) adalah usaha manusia dan perolehannya untuk dirinya sendiri. (Shihab, 2000: 398) Manusia laki-laki dan perempuan tidak sama jenis kemampuannya, sehingga masing-masing memiliki keistimewaan dan kelebihan. Berdasarkan ayat di atas dapat dipahami bahwa hasil usaha suami atau istri adalah merupakan milik dia masing-masing kecuali ada akad baru yang dilakukan untuk merubah status kepemilikan.

Harta bersama dalam perkawinan pada masyarakat didasarkan atas kondisi adat istiadat ('urf) masyarakat dalam suatu negeri yang tidak memisahkan antara hak milik suami dan istri sehingga rasa kebersamaan lebih menonjol. (Zein, 2004: 60) Berkembangnya sikap saling menghormati, saling membantu, saling bekerja sama serta saling ketergantungan antara suami-istri dalam masyarakat adat di Indonesia merupakan kondisi yang mewujudkan harta bersama dalam perkawinan. di Kesultanan Melayu Siak disebut harta pencarian bersama suamiisteri. (Luthfi, 2011: 247)

Kitab-kitab fikih yang tidak membahas harta bersama dalam perkawinan menjadikan pengaturan harta bersama merupakan persoalan baru (kontemporer) yang membutuhkan penetapan hukum atau aturan yang rinci dan jelas, agar keberadaannya dapat mempunyai kepastian hukum dan merupakan harta yang hak untuk dimanfaatkan bagi suami atau istri. 
Sebagaimana Allah peringatkan dalam surat al-Nisa' ayat 29:

"Hai orang yang beriman, janganlah kamu saling memakan harta sesama kamu dengan jalan yang batil, kecuali dengan jalan peniagaan yang berlaku dengan suka sama suka di antar kamu...."(QS. al-Nisa'[3]: 20

Teori penetapan harta bersama dalam perkawinan menurut hukum positif di Indonesia terjadi secara otomatis (ijbari), setelah akad nikah dilakukan secara sah, maka harta pencarian suamiistri sudah termasuk harta bersama dalam perkawinan. Bila suami atau istri menginginkan harta pencarian mereka terpisah menjadi harta pribadi, maka harus melakukan perjanjian perkawinan, artinya harus ada usaha (ikhtiar) atau cara yang dilakukan untuk memisakan harta bersama tersebut. Teori penetapan harta bersama dalam perkawinan menurut Hukum Islam berbeda dengan ketentuan yang ditetapkan dalam hukum positif. Hukum Islam tidak mengatur tentang harta bersama dalam perkawinan. Pemilikkan harta secara otomatis ( ijbari) dalam hukum Islam adalah merupakan milik pribadi orang yang mengusahakan harta itu. Mengalihkan harta pribadi menjadi milik orang lain atau milik bersama dalam perkawinan, tidak bisa terjadi dengan telah terjadinya akad nikah yang sah. harus dilakukan usaha (ihktiar) dengan mengadakan akad baru seperti syirkah, atau perjanjian perkawinan.

PENGABUNGAN HARTA ISTRI DAN HARTA SUAMI MENJADI HARTA BERSAMA (UU NO 1 TAHUN 1974 PASAL 35 DAN KHI PASAL 1 F)

Harta bersama dalam perkawinan ditetapkan secara otomatis, dengan terjadinya akad nikah menurut hukum positif di Indonesia agar menjadi sah dalam pandangan hukum Islam, maka perlu diadakan modifikasi hukum harta bersama dalam perkawinan. Supaya peralihan harta milik pribadi berubah menjadi harta bersama dalam perkawinan, maka harus dilakukan kegiatan (ikhtiar tidak secara ijbari) yang mengakibatkan harta dapat berubah status menjadi harta bersama dalam perkawinan. Minimal dapat dilakukan setelah terjadi akad nikah, oleh suamiistri melafazkan niat bahwa harta pencarian mereka menjadi harta bersama dalam perkawinan. Hal ini harus disaksikan oleh penghulu yang menikahkan supaya peralihan harta tidak menyebabkan syubhat millik.

Harta dalam perkawinan jika dikaitkan dengan prakteknya dalam masyarakat adat tertentu (Rochaity, 2013), maka harta pencarian yang diperoleh suami-istri sebagai milik bersama dalam masa perkawinan dasar modalnya diperoleh suami-istri dari harta bawaan masing-masing dan harta penghasilan masing-masing sebelum perkawinan. Setelah perkawinan terjadi suami-istri membentuk dan membangun rumah tangga bahagia dan kekal, mereka berusaha mencari rezeki bersama-sama sehingga dari harta yang diperoleh seharihari akan dapat terwujud harta kekayaan sebagai hasil pencarian bersama, yang disebut harta pencarian, tanpa memperdulikan apakah suami yang bekerja aktif dan istri mengurus rumah dan anak-anak. Harta pencarian itu, disebut harta bersama suami-istri. Meskipun sumber harta bersama tersebut hanya suami yang bekerja dengan 
berbagai usahanya sedangkan istri berada di rumah dengan tidak mencari nafkah melainkan hanya mengurus rumah tangga dan anak-anaknya, maka harta seperti in dapat dikatakan harta bersama dalam perkawinan. Karena istri berhak menerima nafkah, hibah dan lainnya dari suami. (Zuhaili, 1968)

Nilai-nilai hukum baru dalam harta bersama yang dijelaskan dalam UndangUndang Perkawinan Pasal 35 ayat 1, yang diperkuat dalam Kompilasi Hukum Islam dikemukakan bahwa harta bersama suami istri itu adalah harta yang diperoleh selama ikatan perkawinan berlangsung. Perolehannya tanpa mempersoalkan terdaftar atas nama siapapun. Hal ini berarti bahwa harta bersama itu adalah semua harta yang diperoleh selama perkawinan berlangsung, tanpa mempersoalkan atas nama siapa harta kekayaan itu terdaftar, dan tidak melihat istri punya peran langsung (aktif secara pisik) atau tidak atas terwujudnya harta itu. Penegasan seperti ini antara lain dapat dilihat dalam putusan Mahkamah Agung tanggal 9 Nopember 1976 No: 1448 K/sip/1974. Putusan ini menegaskan “ sejak berlakunya Undang-Undang Nomor 1 Tahun 1974 harta benda yang diperoleh selama perkawinan menjadi harta bersama, sehingga pada saat terjadinya perceraian harta bersama tersebut dibagi sama rata antara bekas suamiistri." (Harahap, 2003: 272)

Melihat awal sejarah diberlakukan konsep harta bersama, dapat dipahami bahwa ide untuk memunculkan pelembagaan harta bersama adalah merupakan wujud perlindungan sekaligus pengakuan terhadap hak-hak istri dalam rumah tangganya, hal ini dapat dikatakan perjuangan keadilan gender. Pada keadaan tertentu terjadi masalah dalam rumah tangga seseorang, istri tidak perlu cemas memikirkan kepentingannya secara materil sebagai bekal memenuhi kebutuhaan dasarnya seperti terjadi perceraian. Pemicu ditetapkan harta bersama dalam perkawinan antara lain kondisi masyarakat pada awalnya yang berfungsi bekerja mencari nafkah adalah suami, maka pemilik mutlak harta yang diperoleh adalah suami. Sedangkan istri tidak mempunyai saham atas terkumpulnya harta dalam perkawinan. Istri bekerja dalam rumah yang tidak menghasilkan uang, tetapi membantu suami untuk menyiapkan dan mengatur keperluan kehidupan dalam rumah tangga. Saat terjadi pisah rumah atau putusnya perkawinan, istri bisa saja tidak punya sesuatu apapun sebagai bekal untuk hidup. Sebagai posisi mengantisipasi kelalaian suami masalah nafkah dan kurang perhatian suami secara materil terhadap istri dan anak-anaknya, maka ditetapkanlah adanya harta bersama. Bila terjadi putus perkawinan, harta bersama diatur menurut hukumnya masingmasing (UU No 11974 Pasal 36) dan atau dibagi dua (KHI Pasal 96 dan 97), sebagian untuk suami dan sebagian lagi untuk istri. Eksistensi harta bersama sangat terasa manfaatnya bagi masyarakat dalam sistem kekerabatan patriarkhi, seperti adat masyarakat Sumatera Utara (Batak), bila suami menceraikan istri atau suami meninggal dunia, maka istrinya tidak berhak tinggal di rumah suami, dan tidak berhak dalam harta dan warisan dari suaminya. Di sisi lain, budaya adat patriarki, tidak memberikan bahagian warisan untuk anak perempuan.

Tujuan menetapkan ketentuan harta bersama dalam Kompilasi Hukum Islam adalah untuk unifikasi, kodifikasi dan tertib hukum, (Atho' Muzdhar, 2003: 2) 
serta pemikiran untuk melindungi hakhak istri dalam harta perkawinan. Penetapan harta bersama dalam UndangUndang dan KHI, berbeda dengan ketentuan fikih. Dalam fikih tidak ada penggabungan harta, kecuali dalam bentuk syirkah, yang untuk itu dilakukan dalam suatu akad khusus untuk syirkah. Tanpa akad tersebut harta tetap terpisah. (Nelli, 2017)

Proses terjadinya harta bersama dipahami dari konsep fikih dapat terjadi bila dilakukan akad percampuran harta yang diperoleh oleh suami dan istri dalam perkawinan (diproses secara ikhtiari). Terjadinya perpindahan status harta pribadi menjadi harta bersama, jika setelah adanya akad nikah yang sah, maka akad perkawinan itu dianggap juga sekaligus merupakan akad untuk harta bersama. Dengan semata telah terjadinya akad nikah maka secara otomatis terjadi harta bersama dalam perkawinan. Hukum Islam menetapkan harta hasil pencarian suami istri merupakan harta pribadi, (Mesraini, 2012) harta pribadi akan menjadi harta bersama bila ada proses perpindahan harta baik dengan perjanjian atau syirkah. Hal ini sesuai dengan kaidah fikih: (sesuatu hak tidak bisa dicabut dari tangan seseorang kecuali atas dasar ketentuan hukum yang tetap). (A Djazuli, 2006: 107) Apa yang diberlakukan di Indonesia berdasarkan UndangUndangNomor 1 tahun 1974 dan KHI, maka proses terjadi harta bersama berlaku secara ijbari setelah akad nikah. Agar harta bersama dapat diterima dalam fikih secara legal dan punya daya usaha (ikhtiari), maka dengan berlangsungnya akad nikah (ijab dan qabul), kedua belah pihak sudah meniatkan untuk menyatu- kan harta pencarian suami-istri menjadi harta bersama. Agar terwujud saling ridha, dalam hal ini kaidah fikih mengatakan (dasar dari akad adalah keridhaan kedua belah pihak). Keridhaan itu adalah perbuatan hati tidak dapat dilihat secara nyata, untuk membuktikan ada keridhaan dilihat dari niat orang yang melakukan akad. Keharusan adanya niat dalam setiap akad adalah berdasarkan hadis Rasulullah SAW yang diriwayatkan Umar bin Al-Khaththab. (Asqalani, 1993: 94)

Pengaruh perkembangan sosial kemasyarakatan, membawa pemahaman yang berbeda terhadap konsep harta bersama dalam perkawinan. Akibat perkembangan selanjutnya terjadi pergeseran dalam keluarga, pemenuhan kebutuhan keluarga dilakukan oleh suami-istri bersama-sama. Suami-istri sama-sama mencari nafkah dan hasil usaha mereka menjadi harta bersama. Hal ini yang ideal sumber harta yang dijadikan harta bersama. Kondisi kekinian, banyak perempuan yang punya penghasilan dari pekerjaanya. Hasil usaha istri itu merupakan sumber utama untuk memenuhi kebutuhan keluarganya. Hasil pencarian istri dalam perkawinan ini dikaitkan dengan aturan harta bersama dalam Undang-Undang Perkawinan dan Kompilasi Hukum Islam maka harta itu menjadi harta bersama dalam perkawinan. Hal ini bila dihubungkan dengan sejarah penetapan harta bersama dalam perkawinan di Indonesia bertujuannya untuk melindungi perempuan yang umumnya tidak punya pencarian, maka tidak pantas di berlakukan terhadap istri yang bekerja sebagai pencari nafkah yang menggantikan tugas suami berkewajiban 
menafkahi istri dan anak-anaknya. Sepatutnya ketentuan tentang harta bersama sudah saatnya untuk ditinjau kembali. Tidak sesuai lagi dengan tujuan penetapan harta bersama untuk melindungi istri. Maka sudah saatnya undang-undang di amandemen. Ketentuan mengenai harta bersama dalam peraturan perundang-undangan di Indonesia belum bisa mengkaver pelbagai kasus yang terjadi dewasa ini, sehingga diperlukan amandemen. (Mesraini, 2012)

Harta yang berasal dari pencarian istri dapat menjadi harta bersama atas keridhaannya dibuat perjanjian menetapkan harta yang diperoleh istri dalam perkawinan menjadi harta bersama suami-istri. Bila harta hasil pencarian istri dijadikan modal usaha suami istri, maka harta bersama dapat terjadi dengan adanya syirkah dalam perkawinan. Terjadinya perpindahan status harta pribadi istri menjadi harta bersama, jika setelah adanya akad harta bersama, maka baru terdapat harta bersama dalam perkawinan. Dengan semata telah terjadinya akad nikah tidak dengan sendirinya terjadi harta bersama. Harta bersama itu terjadi secara ikhtiari. Harta bersama dalam perkawinan menurut fikih dapat terjadi dalam 2 (dua) bentuk, yaitu pertama adanya akad syirkah antara suami -istri, baik dibuat saat berlangsungnya akad nikah atau sesudahnya. Kedua, adanya perjanjian ya ng dibuat untuk itu pada waktu berlansungnya akad nikah. (Syarifuddin, 2009: 175-176)

\footnotetext{
HARTA BERSAMA DALAM PERKAWINAN DAN PENGARUHNYA TERHADAP KEWAJIBAN SUAMI MEMBERI NAFKAH KEPADA ISTRI DAN ANAK-ANAK (UU NO 1 TAHUN
}

1974 PASAL 34 AYAT (1) DAN KHI PASAL 80 AYAT(4)

Pengertian harta bersama yang dijelaskan dalam undang-undang dan KHI, membawa pemahaman yang rancu terhadap ketentuan kewajiban suami menafkahi keluarganya, bagaimana pelaksanaannya nafkah bagi keluarga yang mengikuti prinsip harta bersama dan apa bedanya dengan keluarga yang tidak mengikuti prinsip harta bersama. Manakala Undang-Undang menyatakan harta pencarian dalam perkawinan termasuk harta bersama, tentunya kebutuhan rumah tangga diutamakan bersumber dari harta bersama, dengan pengertian suami tidak dituntut lagi untuk membayar nafkah sebagaimana yang disebutkan dalam Undang Undang dan KHI.

Suami-istri yang menggabungkan hartanya menjadi harta bersama dengan kerelaan, maka kebutuhan keluarga haruslah diambilkan dari harta bersama itu. Artinya suami tidak dapat dituntut lagi memberi nafkah pada keluarganya Konsep harta bersama ini merupakan pembaruan hukum (fikih kontemporer), tentunya punya implikasi terhadap kewajiban suami menafkahi istri dan anak-anaknya. Ketentuan pasal 35 UU No. 1 tahun 1974 menetapkan harta bersama membawa pemahaman yang rancuh terhadap pelaksnanan kewajiban suami yang di jelaskan dalam Pasal 34 ayat (1) bahwa suami wajib melindungi isterinya dan memberikan segala sesuatu keperluan hidup berumah tangga sesuai dengan kemampuannya. Terjadi kontradikti yang tidak punya keselarasan dengan apa yang diatur dalam harta bersama dalam perkawinan. Pola keluarga yang telah ditetapkan dalam 
fikih klasik mengatur harta menjadi milik pribadi, menganut paham pemisahan harta secara induvidual bukan kolektif. Suami-istri yang mengabungkan hartanya menjadi harta bersama dengan dasar kerelaan, maka akan berakibat harta menjadi bercampur dan kebutuhan keluarga tentunya diambilkan dari harta bersama ini. Jika suami masih ditutut memberi nafkah untuk istri dan anakanaknya, timbul pertanyaan dari harta mana suami memeberikan kewajibannya karena harta pencaharian sudah bercampur dalam harta bersama.

Terhadap harta bersama, maka suami dan istri adalah sebagai pemilik bersama, sehingga setiap perbuatan hukum yang terkait dengan pengelolaan harta bersama, merupakan tanggung jawab dan hak bersama. (Erwinsyahbana, 2017) Diterapkannya konsep harta bersama, maka nafkah menjadi tanggungjawab bersama suami istri. Nafkah bisa saja menjadi kewajiban suami, namun harus diterapkan pemisahan harta suami istri dalam perkawinan, atau dengan mengkompromikan antara harta bersama dan kewajiban suami memberi nafkah. Ini dilakukan dengan memberi penambahan aturan dalam Pasal 80 KHI mengenai jenis harta yang dapat dipakai untuk memberi nafkah, yaitu harta pribadi dan atau harta yang diperoleh suami selama perkawinan. (Nelli, 2017)

\section{PEMBAHAGIAN HARTA BERSAMA BILA TERJADI PERCERAIAN (KHI PASAL 96 DAN 97 SERTA PASAL 94 DAN 95)}

Pembagian harta bersama apabila terjadi putusnya perceraian atau kematian salah satu suami istri, Kompilasi Hukum Islam menjelaskan kedudukan harta bersama bila terjadi perceraian Ayat (1) menyatakan apabila terjadi cerai mati, maka sebagian harta bersama menjadi hak pasangan yang hidup lebih lama. Pasal 97, janda atau duda cerai hidup masingmasing berhak seperdua dari harta bersama sepanjang tidak ditentukan lain dalam perjanjian perkawinan. Memahami pasal ini menimbulkan pertanyaan apa dasar hukumnya menetapkan harta bersama itu dibagi dua tanpa memperhatikan partisipasi dominan harta bersama. Sumber harta lebih banyak bersumber dari penghasilan kerja suami atau istri. Kondisi saat ini yang sumber ekonomi keluarga banyak dibantu oleh hasil pencarian istri, ketentuan harta bersama dibagi dua perlu dilakukan perubahan. (Mesraini, 2012)

Pembahagian harta bersama setengah untuk suami dan setengah untuk istri yang diatur Kompilasi Hukum Islam, dalam kasus-kasus tertentu dapat dilenturkan, (Hamdi, 2018) mengingat realitas kehidupan keluarga di beberapa daerah di Indonesia, ada pihak suami yang tidak berpartisipasi dalam membangun ekonomi rumah tangga, dalam hal ini para praktisi hukum lebih hati-hati dalam memeriksa kasus-kasus tersebut agar memenuhi rasa keadilan, kewajaran dan kepatutan. (Manan, 2012: 129) Ketentuan pembahagian harta bersama dibagi dua, tidaklah mutlak dalam penyelesaian harta bersama, (UU perkawinan Pasal 36) partisipasi istri dalam mewujudkan harta bersama keluarga dapat menjadi pertimbangan khusus bagi hakim. sehingga bahagian yang menetapkan setengah dari harta 
bersama untuk istri dan suami dalam kasus-kasus tertentu perlu dilakukan perubahan. Hakim dalam menyelesaikan perkara-perkara yang diajukan kepadanya, wajib memperhatikan dengan sungguh-sungguh nilai-nilai hukum yang hidup dalam masyarakat (KHI Pasal 229), sehingga putusannya sesuai dengan rasa keadilan, kewajaran, dan kepatutan. Ketentuan membagi dua harta bersama bila terjadi perceraian adalah berdasarkan apa diatur dalam Kitab Undang-Undang Hukum Perdata Pasal 128-129. Sedangkan menurut ketentuan fikih pembagian harta syirkah berdasarkan kesepakatan kedua belah pihak yang bersyerikat.

Pembahagian harta bersama dalam perkawinan yang suami poligami sulit memahaminya apa yang ditetetapkan dalam KHI Pasal 94 dan 95. Hal ini dilihat dari cara mengitung harta bersama terhadap suami dengan masing-masing istrinya, baik dilihat dari lama suami bergaul dengan masing-masing istrinya ataupun dilihat dari harta yang termasuk harta bersama. Berikut ini dapat dilihat aspek yang mempengaruhi pembahagian harta bersama suami yang poligami, pertama, lamanya usia perkawinan antara suami dengan masing-masing istrinya. Kedua, keaktifan istri-istri dalam kerja dan penghasilannya, atau dominasi partisipasi saham istri-istri terwujudnya harta bersama. Ketiga, beban keluarga dan belanja rumah tangga masing-masing istri

Hal-hal yang disebutkan di atas menjadi pertimbangan hakim dalam penyelesaian kasus harta bersama yang suami poligami, agar pembahagian harta bersama memenuhi rasa keadilan masyarakat dalam upaya mengisi kekosongan hukum.
Menganalisis putusan hakim tentang pembahagian harta bersama dalam perkawinan, berdasarkan penelitian yang dilakukan Mesraini (Mesraini, 2012) dari enam belas putusan yang dijadikan sampel dalam penelitian ini diketahui bahwa putusan pembagian harta bersama tidak keluar dari aturan KHI yang menghendaki pembagian bagi suami dan isteri dengan membagi dua sama banyak nilainya, baik dalam kasus suami dan istri yang sama-sama bekerja maupun salah satu pihak yang bekerja. Selain itu, hakim juga memutuskan pembagian harta bersama didasarkan atas kesepakatan atau perdamaian. Dalam perkara perkara tertentu, terdapat berbagai pertimbangan dan putusan hakim sesuai dengan kondisi dan andil usaha masing-masing suami dan istri. Ada hakim yang menetapkan membagi harta bersama $1 / 3$ untuk suami, $1 / 3$ untuk istri, dan $1 / 3$ untuk anak sebagaimana yang putusan perkara nomor: 369/pdt.G/2008/PA.BKT. Putusan Hakim Pengadilan Bukit Tinggi Nomor 618/Pdt. g/2012/PA.Bt memutuskan harta bersama dibagi $1 / 3$ (satupertiga) untuk Penggugat (suami) dan 2/3 (duapertiga) hak Tergugat (isteri). Hakim dapat mengesampingkan ketentuan Kompilasi Hukum Islam pasal 97, apabila dalam persidangan ditemukan fakta-fakta yang dapat menjadi pertimbangan memutus perkara berdasarkan kontribusi suami-istri perolehan harta dalam perkawinan Hakim tidak hanya "labauchedelaloi" (corong undang-undang), tetapi dituntut memiliki keberanian mengambil putusan berbeda dengan normatif undang-undang apabila hukum tersebut sudah tidak sesuai dengan perubahan sosial di masyarakat. (Kurniawan, 2017) Yurisprodensi Putusan Kasasi di Mahkamah Agung perkara 
nomor: 266/AG/2010 menetapkan pemba-hagian harta keluarga $3 / 4$ untuk istri dan 1/4 untuk suami dengan pertimbangan suami tidak memberi nafkah dari hasil kerjanya dan seluruh harta bersama diperoleh istri dari hasil kerjanya. putusan Pengadilan Agama Nomor:0189/Pdt.G/2017/PA.Smg.Hakim menetap pembahagian harta istri $3 / 4$ bagian sedangkan suami $1 / 4$ bagian. Putusan hakim mencerminkan keadilan distributif berdasarkan azas keseimbangan atau memberikan hak berdasarkan prestasi atau partisipasi. (Pratama, 2018) Penggalian hukum baru yang berbeda oleh hakim menimbulkan variasi putusan agar mempunyai kepastian hukum, maka peraturan yang ada sudah saatnya untuk diamandemen memberikan aturan tambahan dalam pasal-pasal tertentu. Ketentuan mengenai harta bersama dalam peraturan perundang-undangan di Indonesia belum bisa mengkaver pelbagai kasus yang terjadi dewasa ini. (Mesraini, 2012) Hal ini dilakukan untuk mewujudkan tujuan hukum memberikan rasa keadilan, kewajaran dan kepatutan

\section{KESIMPULAN}

Supaya peralihan harta milik pribadi berubah menjadi harta bersama dalam perkawinan, maka harus dilakukan kegiatan (ikhtiar tidak secara ijbari) yang mengakibatkan harta dapat berubah status menjadi harta bersama dalam perkawinan. Minimal dapat dilakukan setelah terjadi akad nikah, oleh suamiistri melafazkan niat bahwa harta pencarian mereka menjadi harta bersama dalam perkawinan. Hal ini harus disaksikan oleh penghulu yang menikahkan supaya peralihan harta tidak menyebabkan syubhan millik. Ketentuan mengenai harta bersama dalam peraturan perundang-undangan di Indonesia belum bisa mengkaver pelbagai kasus yang terjadi dewasa ini, sehingga diperlukan amandemen terhadap harta bersama, maka suami dan isteri adalah sebagai pemilik bersama, sehingga setiap perbuatan hukum yang terkait dengan pengelolaan harta bersama, merupakan tanggung jawab dan hak bersama.

Menerapkan konsep harta bersama dalam perkawinan, maka nafkah menjadi tanggungjawab bersama suami istri. Nafkah bisa saja menjadi kewajiban suami, namun harus diterapkan pemisahan harta suami istri dalam perkawinan, atau dengan mengkompromikan antara harta bersama dan kewajiban suami memberi nafkah. Ini dilakukan dengan memberi penambahan aturan dalam Pasal $80 \mathrm{KHI}$ mengenai jenis harta yang dapat dipakai untuk memberi nafkah, yaitu harta pribadi dan atau harta yang diperoleh suami selama perkawinan. Putusan hakim bervariasi dalam pembahagian harta bersama yang mencerminkan keadilan distributif berdasarkan azas keseimbangan atau memberikan hak berdasarkan prestasi atau partisipasi. Pengalian hukum baru menimbulkan putusan berbeda oleh hakim, terdapat variasi putusan. Putusan hakim yang bervariasi agar mempunyai kepastian hukum, maka peraturan yang ada suda saatnya untuk diamandemen memberikan aturan tambahan dalam pasal-pasal tertentu. Ketentuan mengenai harta bersama dalam peraturan perundangundangan di Indonesia belum bisa mengkaver berbagai kasus yang terjadi 
dewasa ini. Hal ini dilakukan untuk mewujudkan tujuan hukum memberikan rasa keadilan, kewajaran dan kepatutan

\section{DAFTAR PUSTAKA}

A Djazuli. (2006). Kaidah-kaidah Fikih: Kaidah-kaidah Hukum Islam dalam Menyelesaikan Masalah-masalah yang Praktis. Jakarta: Pranata Media.

Arifin, B. (1996). Pelembagaan Hukum Islam di Indonesia, Akar Sejarah Hambatan dan Prospeknya. Jakarta: Gema Insani Press.

Asqalanim, I. H. (1993). Fathu Bari Syarhi Syarah al-Bukhari. Beirut: Dar al-Fikr.

Atho' Muzdhar, K. N. (2003). Hukum Keluarga di Dunia Islam Moderen. Jakarta: Ciputat Press.

Bushar, M. (1998). Pokok-pokok Hukum Adat. Jakarta: PT Pradnya Paramita.

Dahlan, A. A. (1997). (et al) Ensiklopedin Hukum Islam. Jakarta: PT. Ichtiar Baru Van hoeve.

Elimartati. (2018). Harta Kekayaan dalam Perkawinan Menurut Hukum Islam dan Hukum Positif di Indonesia, dalam Kajian Pengarusutamaan Jender. Yogyakarta: Dialektika.

Erwinsyahbana, V. L. F. T. (2017). Kepastian Hukum Penggadaian Harta Bersama Tanpa Izin Dari Salah Satu Pasangan Dalam Perkawinan (Analisis Putusan Mahkamah Syar'iyah Nomor: 0049/Pdt.G/2014/Ms-Aceh). , Jurnal UMSU, 13(1).

Hamdi, I. (2018). Perluasan Makna Harta Bersama Perspektif Sosiologi Hukum Islam. Jurnal Ilmiah Syari'ah, 17(1).
Harahap, M. Y. (2003). Kedudukan Kewenagan dan Acara Peradilan Agama. Jakarta: Sinar Grafika.

Ismuha. (1978). Pencarian Bersama Suami Istri di Indonesia. Jakarta: Bulan Bintang.

Kurniawan, B. (2017). Pembagian Harta Bersama Berdasarkan Kontribusi Dalam Perkawinan Jurnal Ilmu Syariah. 17(2). Jurnal Ahkam, Jurnal Ilmu Syariah., 17(2).

Luthfi, A. (2011). Hukum \& Perubahan Struktur Kekuasaan Pelaksanaan Hukum Islam dalam Kesultanan Melayu Siak 1901-1942. Pekanbaru: Suska Press.

Manan, A. (2012). Aneka Masalah Hukum Perdata Islam di Indonesia. Jakarta: Kencana.

Mesraini. (2012). Konsep Harta Bersama Dan Implementasinya Di Pengadilan Agama. Jurnal Ahkam, 12(1).

Nelli, J. (2017). Analisis Tentang Kewajiban Nafkah Keluarga Dalam Pemberlakuan Harta Bersama. Jurnal Istinbat, 2(1).

Pratama, A. (2018). Implementasi Percampuran Harta Bersama Dan Harta Bawaan Dalam Perkawinan (Studi Kasus Putusan Pengadilan Agama Nomor: 0189/Pdt.G/2017/Pa.Smg). Urnal Ius Constituendum., 3(1).

Rochaity, E. (2013). Analisis Yuridis Tentang Harta Bersama (Gono Gini) Dalam Perkawinan Menurut Pandangan Hukum Islam Dan Hukum Positif. Jurnal Wawasan Hukum, 28(1).

Shihab, Q. (2000). Tafsir Al Misbah. Jakarta: Lentera Hati. 
Syarifuddin, A. (1984). Pelaksnaan Hukum Kewarisan Islam dalam Lingkungan Adat Minangkabau. Gunung Agung.

Syarifuddin, A. (2009). Hukum Perkawinan Islam di Indonesia. Jakarta: Kencana.

Thalib, S. (1986). Hukum Kekeluargaan Indonesia Berlaku bagi Umat Islam. Jakarta: UI Press.
Zein, S. E. M. (2004). Problematika Hukum Keluarga Islam Kontemporer. Jakarta: Kencana.

Zuhaili, W. (1968). Figh al-Islam wa Adilatuhu. Damaskus: Dar al-Fikr. 